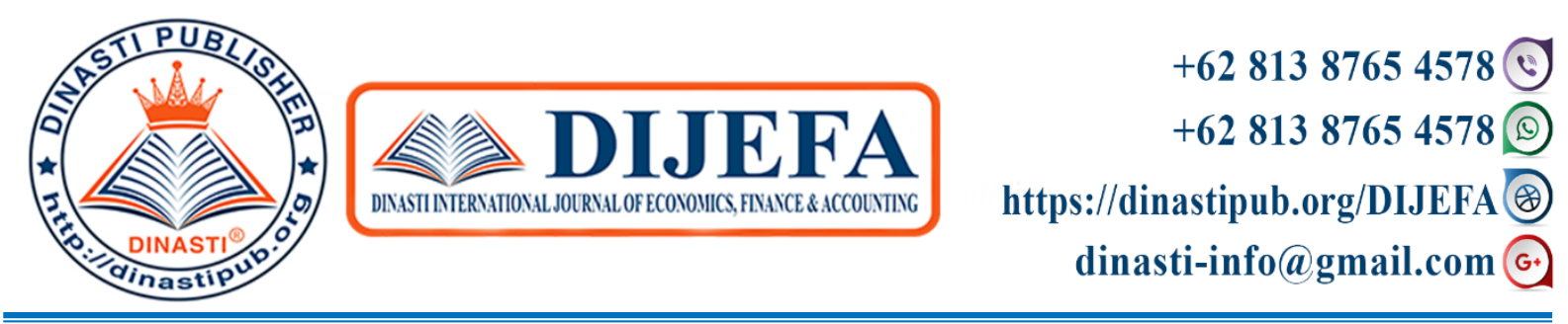

\title{
THE EFFECT OF EASE OF USE, RISKS TOWARDS CONSUMER DECISIONS WHEN SHOPPING ONLINE
}

\section{Dede Suleman ${ }^{1}$, Dedi Suharyadi' ${ }^{2}$, Sofyan Marwansyah ${ }^{3}$, Susan Rachmawati ${ }^{4}$, Sri Rusiyati $^{5}$, Sabil Sabil ${ }^{6}$ \\ 1,2,3,4,6) Bina Sarana Informatika University, Jakarta, Indonesia \\ ${ }^{5)}$ Sekolah Tinggi Manajemen Informatika dan Komputer Nusa Mandiri, Jakarta,Indonesia}

\begin{tabular}{|c|l|}
\hline $\begin{array}{c}\text { ARTICLE INFORMATION } \\
\text { Received: 10 August 2020 } \\
\text { Revised: 28 August 2020 } \\
\text { Issued: 13 September 2020 }\end{array}$ & $\begin{array}{l}\text { Abstract: The presence of various alternative } \\
\text { shopping places makes consumers choose one of the } \\
\text { available shopping places. Therefore this study aims to } \\
\text { analyze the relationship between ease and risk of } \\
\text { consumer decisions to buy fashion products, especially } \\
\text { in online retail. the population in this study is large and } \\
\text { the number is not known with certainty, so in the non } \\
\text { probalitiy research that is using sampling quota } \\
\text { sampling techniques with survey methods with a total } \\
\text { sample of 100 respondents from the city of Jakarta } \\
\text { with criteria respondents aged over 18 years in the area } \\
\text { of DKI Jakarta and have bought products online. The } \\
\text { results of the study stated that ease of use has a } \\
\text { significant influence on consumer decisions. While the } \\
\text { risk turns out to influence consumer decisions in } \\
\text { shopping online. The results of this study can be } \\
\text { another reference for further research. }\end{array}$ \\
DOI:10.38035/DIJEFA & $\begin{array}{l}\text { Keywords: Ease of use, Risk and decision to online } \\
\text { shop. }\end{array}$
\end{tabular}

\section{INTRODUCTION}

In the development of the era there has been a change in consumer spending patterns where the presence of this new era has made the emergence of alternative shopping patterns namely online retail. Indonesia is a potential country because of the high population and internet users this could be the perfect market for online retailing in the years to come (Suleman, 2018)The online retail method is strongly influenced by internet access that supports each transaction process (Widyadara, 2018). in other countries online retailing is growing rapidly (Tao \& Xu, 2018). The emergence of the 4.0 era is an era where online retail and offline retail win markets and consumers, but these two retailers are not in fact not beating each other but complement each other (Kotler et al., 2019). The presence of two 
alternative shopping places offers a perfect market competition, in offering goods to consumers because consumers are currently free to set prices because of the variety of offers available for the same goods as many offers offered in offline retail and online retail (Loudon et al., 2012). This internet not only has a revolutionary impact on people's lives, but also has its effect on marketing operations (Al-Debei et al., 2015) .

Consumers often choose where to shop online because there are many advantages offered. Another advantage of online retailing is that location is no longer a barrier to transactions (Blut, Frennea, Mittal, \& Mothersbaugh, 2015), (Suleman et al., 2020). In recent years online shopping has begun to attract the attention of consumers because of its ease and completeness, especially among young people and adolescents with a large amount of growth, but shopping for offline shopping methods still cannot be said to be defeated because it is still the main choice for today's adult consumers (Nazzal et al., 1988). Ease is also a variable that is always examined together with its usefulness because it is used to measure how consumer acceptance of changes in the presence of new technology and it turns out that ease is also a factor that influences consumer attitudes and consumer decisions (Hsu et al., 2013). When consumers make transactions at online retail, then what consumers think is that the money sent does not just disappear but will later get the desired product reply in accordance with what is displayed (Ariwibowo et al., 2013)Risk is also a matter of concern but several studies have shown that risk does not affect consumer decisions when transactions are detailed online because the technological sophistication of existing transaction risks is small and not a consideration for consumers (Zolait et al., 2018) and (Suleman, Ali, et al., 2020b).

This is where purchasing decisions are made by consumers who will ultimately decide to choose a shopping place that can offer a lot of convenience to the alternative and also see how risky one of the retail shopping is in terms of certainty in the transaction (Suleman, Zuniarti, Marginingsih, et al., 2019) and (Zuniarti et al., 2020). Ease factors have been investigated and the results found that a purchasing decision can be due to the convenience obtained from a shopping place (Suleman, Zuniarti, Setyaningsih, et al., 2019). Ease is also a major supporting factor in consumer decisions than other factors (Suleman, Zuniarti, \& Sabil, 2019). However, the current risk factor is less considered by consumers because consumers feel online retail is currently far better because of the presence of various kinds of platforms that facilitate consumers in shopping. Therefore risk is considered not to influence consumers' decisions in choosing one of the shopping places (Suleman, Ali, et al., 2019), (Suleman, Ali, et al., 2020a). This research will produce an overview of the influence of how ease of use and risk play a role in consumer decisions.

\section{PURPOSED TO STUDY}

To investigate the convenience of consumers and the risks to consumers' decision to choose where to shop. This convenience is often used in theoretical TAM frame work consisting of usability and convenience (Ajzen, 1985). TAM is often used because it is devoted to researching how a new technology impacts behavior change. For this risk is rarely used in research related to the use of new technology so researchers want to know whether the risk still has no influence on consumer buying decisions. In research (Zuniarti et al., 2020) and (Suleman, Suharyadi, et al., 2020) found that ease of use and risk affect consumer 
decisions Even though there is a big risk when we do shopping at online retail. With the hypothesis in this study

H1: There is an influence between ease of use and buying decision

$\mathrm{H} 2$ : There is no influence between risk and buying decision.

\section{RESEARCH METHODS}

The populations in this study are consumers who have shopped in offline and online retail therefore the population is infinite and the number is uncertain. Therefore the researcher took a sample with non-probability sampling method with quota sampling with the number of samples to be taken as many as 100 samples with the number of samples up to $5 \mathrm{x}$ the number of indicators in this study (Sugiyono, 2013). The results A survey of 140 consumers was conducted to collect data in this study. However, only the questionnaire responses returned returned to meet the quota of 100 respondents who filled out completely and were received at the end of the data collection period.

\section{FINDINGS AND DISCUSSION}

First, the validity and reliability test in the construct in this study found that of the 3 variables used with 20 indicators in this study all were found to be valid and reliable. With a range of $85.06 \%$ of the total variance described, and loading of items ranging from .83 to 1.16. Cronbach's alphas range from 0.75 to 0.93 . Furthermore, the output results from the confirmatory factor analysis (CFA) model in this study can be concluded that a good fit model $(\chi 2 / \mathrm{df}=1.42, \mathrm{p}<.001, \mathrm{RMSEA}=.066, \mathrm{CFI}=.947$, and GFI $=.814)$. In the analysis of the path used to test the hypothesized relationship. The results show that there is an influential and significant relationship between the ease of online shopping and the decision to buy. And also the risk also turned out to be very significant influence on buying decisions. So the results are accepted $\mathrm{H} 1$ research hypothesis and $\mathrm{H} 2$ rejected.

\section{CONCLUSION AND SUGESTION}

The conclusion that can be drawn from this research is that there are findings from this study. First, as suggested by the TAM Model, convenience associated with consumer behavior significantly influences consumer decisions. Secondly, regarding the risk that also turns out to produce significant results affecting consumer decisions. In this case, consumers choose to shop at retail online because of the convenience factor, the easier it is, the more retail online becomes a choice for consumers' shopping and the risk remains to be a concern of consumers when deciding to shop because the assumptions we expect when technology is more sophisticated, there are many platforms that minimize risk in transactions compared to before online transactions between direct sellers and buyers. But apparently it has not been able to avoid the effect of risk considerations on consumer decisions because risk factors remain a concern of consumers when making transactions, especially online transactions.

\section{IMPLICATION AND FUTURE RESEARCH}

The results of this study can provide an overview and major implications for marketers in marketing targets in online retail. Where the key in online marketing is how to make it easier for consumers to make transactions while online retailing can provide this convenience, consumers will be able to change their buying decisions. And also for risk, it 
also remains the main when making transactions although there are currently many facilities provided to minimize risk, but consumers are still worried about making transactions online and still comparing the security of transactions in offline details. Therefore, marketers must create solutions to this matter in order to better contribute consumer risk when transacting online. The next study is expected to be able to add other variables that influence consumer decisions and broaden the scope of the population and also increase the number of samples.

\section{REFERENCE}

Ajzen, I. (1985). From Intentions to Actions: A Theory of Planned Behavior. Action Control, 11-39. https://doi.org/10.1007/978-3-642-69746-3_2

Al-Debei, M. M., Akroush, M. N., \& Ashouri, M. I. (2015). Consumer attitudes towards online shopping: The effects of trust, perceived benefits, and perceived web quality. Internet Research, 25(5), 707-733. https://doi.org/10.1108/IntR-05-2014-0146

Ariwibowo, J., Nugroho, D. P., \& Adhi, M. (2013). Pengaruh Trust Dan Perceived of Risk Terhadap Niat Untuk Bertransaksi Menggunakan E-Commerce. Nominal, Barometer Riset Akuntansi Dan Manajemen, 2(1), pp 11-35. https://doi.org/10.21831/nominal.v2i1.1646

Hsu, C. L., Lin, J. C. C., \& Chiang, H. Sen. (2013). The effects of blogger recommendations on customers' online shopping intentions. Internet Research, 23(1), 69-88. https://doi.org/10.1108/10662241311295782

Kotler, P., Kartajaya, H., \& Setiawan, I. (2019). Marketing 4.0: Moving From Traditional To Digital. In Gramedia. PT. Gramedia Pustaka Utama. https://doi.org/10.1142/9789813275478_0004

Loudon, D., Stevens, R., \& Wrenn, B. (2012). Marketing management: Text and cases. In E. Belas (Ed.), Marketing Management: Text and Cases. Pearson Education Limited . https://doi.org/10.4324/9780203862261

Nazzal, A. I., Lee, V. Y., Engler, E. M., Jacowitz, R. D., Tokura, Y., \& Torrance, J. B. (1988). New procedure for determination of $[\mathrm{Cu}-\mathrm{O}]+\mathrm{p}$ charge and oxygen content in high Tc copper oxides. Physica C: Superconductivity and Its Applications, 153-155(1), 1367-1368. https://doi.org/10.1016/0921-4534(88)90324-3

Sugiyono. (2013). Metode penelitian manajemen. Badan Penerbit Universitas Diponegoro.

Suleman, D. (2018). Faktor Penentu Keputusan Konsumen Indonesia MemilihTempat Belanja Disebuah E-Commerce (Theory of Planned Behavior). Jurnal JDM, I(02), 1-9. http://journal.mercubuana.ac.id/index.php/jdm/article/view/4120

Suleman, D., Ali, H., Nusraningrum, D., \& Ali, M. M. (2020a). Faktor konsumen dalam memilih tempat belanja di Era 4.0. At-Tijaroh, 6(1), Pp : 37-44.

Suleman, D., Ali, H., Nusraningrum, D., \& Ali, M. M. (2020b). Strategi memenangkan persaingan bisnis berbasis perilaku konsumen untuk produk fashion. Lembaga pendidikan dan pelatihan balai insan cendekia.

Suleman, D., Ali, H., Nusraningrum, D., \& Ali, M. M. A. (2019). Perceived Ease of Use, Trust and Risk toward Attitude and Intention in Shopping for Online Fashion Products In Indonesia. Archives of Business Research, Vol.7(No.4), pp.240-253. https://doi.org/DOI: http://dx.doi.org/10.14738/abr.74.2019

Suleman, D., Ali, H., Nusraningrum, D., \& Ali, M. M. (2020). Consumer Behaviour in the Marketing 4.0 Era Regarding Decisions about Where to Shop. International Journal of Innovation, Creativity and Change, 13(7), $\mathrm{Pp}: 444-456$. https://www.ijicc.net/images/vol_13/Iss_7/13763_Suleman_2020_E_R.pdf

Suleman, D., Suharyadi, D., Rusiyati, S., Sabil, Riftiasari, D., \& Marwansyah, S. (2020). How trust,risk toward attitude when shopping retail online. Dinasti International Journal of Education Management and Social Science, 1(4), Pp:487-492. https://doi.org/https://doi.org/10.31933/dijms.v1i4.185

Suleman, D., Zuniarti, I., Marginingsih, R., Sabil, Nurhayaty, E., Rachmawati, S., Pramularso, E. Y., 
\& Sari, I. (2019). Competition between offline and online stores: when it comes to shopping for fashion products, which store will be the choice of Indonesian consumers? International Conference on Global Innovation and Trends in Economy, 1-14. https://easychair.org/publications/preprint/8drP

Suleman, D., Zuniarti, I., \& Sabil, S. (2019). Consumer Decisions toward Fashion Product Shopping in Indonesia: The effects of Attitude, Perception of Ease of Use, Usefulness, and Trust. Management Dynamics in the Knowledge Economy, 7(2), 133-146. https://doi.org/10.25019/mdke/7.2.01

Suleman, D., Zuniarti, I., Setyaningsih, E. D., Yanti, V. A., Susilowati, I. H., Sari, I., Marwansyah, S., Hadi, S. sudarmono, \& Lestiningsih, A. S. (2019). Decision Model Based on Technology Acceptance Model (Tam) for Online Shop Consumers in Indonesia. Academy of Marketing Studies Journal, 23(4), Pp: 1-14. https://www.abacademies.org/articles/decision-model-basedon-technology-acceptance-model-tam-for-online-shop-consumers-in-indonesia-8624.html

Tao, Q., \& Xu, Y. (2018). Consumer Adoption of Fashion Subscription Retailing: The Moderating Effect of Experiment with Appearance. International Textile and Apparel Association (ITAA) Annual Conference Proceedings, Pp. 1-3.

Widyadara, M. A. (2018). Analisis Faktor-Faktor Pengaruh Minat Belanja Konsumen Pada Toko Online Berrybenka. Generation Journal, Vol. 2(No. 2 Juni), pp 33-41.

Zolait, A. H., Isa, S. M., Ali, H. M., \& Sundram, V. P. K. (2018). Men vs. Women: Study of online shopping habits and factors influencing buying decisions in Bahrain. International Journal of EServices and Mobile Applications, 10(4), 61-73. https://doi.org/10.4018/IJESMA.2018100104

Zuniarti, I., Suleman, D., Rachmawati, S., Sabil, \& Rusiyati, S. (2020). How Ease of use, usefullness toward attitude of shopping at online retail. Dinasti International Journal of Education Management and Social Science, 1(4), Pp:448-453. https://doi.org/https://doi.org/10.31933/dijemss.v1i4.211 